\title{
FAMILY AND CAREER RECONCILIATION: FAMILY, EMPLOYER AND CAREER COUNSELLOR PERSPECTIVES
}

\section{TAMOLIŪNE் Giedrè}

Vytautas Magnus University, Academy of Education, Kaunas, Lithuania

\section{TREPULE் Elena}

Vytautas Magnus University, Academy of Education, Kaunas, Lithuania

\section{TANDZEGOLSKIENE் Ilona}

Vytautas Magnus University, Academy of Education, Kaunas, Lithuania

\begin{abstract}
The discussions about work and family reconciliation have revealed the fact that it is essential to talk about division of roles and agreements in the family, the skills important for career management, "here and now" search for the solutions to various problematic situations, flexibility and ability to get involved in work activity at the same time respecting family needs. Seeking reconciliation of family and career, family needs have been linked to positive parenthood and at the same time work tendencies and career opportunities have been estimated. Here we face some obstacles which are common to the aspiration of harmony and satisfaction in family, work or while developing career opportunities. The goal of this empirical study - to discuss common grounds and distinguish needs and challenges of young families, employers and career counsellors for successful reconciliation of family and career. A qualitative research included narratives of young parents, interviews with employers and a focus group interview with career counsellors. The data received from the narrative has been interpreted according to thematic analysis method and the interview data of focus group has been presented by dividing the data into categories and subcategories. Results have demonstrated that young parents' experiences intertwine with employers' experiences in some cases while career counsellors are
\end{abstract}




\section{sciendo}

10.2478/arhss-2018-0004 Applied Research in Health and Social Sciences, Vol. 15, No. 1, 2018

expected to provide guidance and support to facilitate the potential conflict although there are still gaps in this service provision.

Keywords: Career; Career counsellor; Family-career reconciliation; Family-work conflict.

\section{Background}

Nowadays, when social family roles that were common earlier is changing, as women are seeking to concentrate not only onto taking care of the family and growing children but as well to achieve higher positions in their careers, and men are taking more responsibilities when growing a child and involving themselves into parenting, balancing this process is really challenging. Even though there are many institutions and participants involved in this process, there still is a gap between theoretical and legal aspects of balancing work and family, and practical collaboration and communication among three main agents of this process, i.e. parents, employers and experts in career counselling. Authors of the research presented in this article use the concept of family through the perspective of parenthood that is a social factor that is based on common union and activities between father and mother, their mutual consensus, unity and coherence in order to create positive microclimate (Wayne et al., 2004) and secure welfare of a child / children while growing and nurturing him. Authors of this study did not investigate the implications to the career and family reconciliation in the cases of single parents, homosexual families or in terms of different ethnic or cultural situations, as well as it did not seek to represent young parents' experience through gender perspective.

Coser (1974) defines family and work as greedy institutions as both have high demands and expectations from their members. This process requires active involvement of employees during work time and being active and responsible parents independently from work sector, hours or duties (Moen, 2003; Ahmad, 2007, 2008). While at the same time, every employer expects a loyal and hardworking worker who can cope with duties without being distracted by family issues while being at work. In the process of changes in society parents must find new ways to accommodate working hours, performance and family duties. In order to achieve this, experts in career counselling are expected to facilitate the intensity that might appear between employer and a young parent by consulting and informing both parts about their rights. Experts in career counselling help individuals to rethink their career decisions, encourage to make changes at work, and in this way, to achieve better parenting- 


\section{sciendo}

10.2478/arhss-2018-0004 Applied Research in Health and Social Sciences, Vol. 15, No. 1, 2018

career balance (Neault \& Pickerell, 2005; Wayne, Musisca, \& Fleeson, 2004). It can be implemented by introducing them to different strategies helping to balance work and family, offering possibilities to learn about mechanisms by which personality may influence conflicts or facilitation (Wayne, Musisca, \& Fleeson, 2004). Nevertheless, the literature review proves that counselling services as well as employee assistance programs at work are not very well-affected by those who need that support (Neault \& Pickerell, 2005).

Research presented in this paper provides an added value to the research of this field by combining all three main target groups under one perspective as well as focusing mainly on young parents' parenthood experiences and career life, nevertheless, the involvement of both parents (mother and father) is important. Research question underlying this study are: How do families, employers and career counsellors see, act and understand the process of family and career reconciliation? What common ground could be found for collaboration among target groups?

\section{Aim}

The aim of this empirical study is to discuss common grounds and distinguish needs and challenges of young families, employers and career counsellors for successful reconciliation of family and career.

\section{Methodology}

\section{Research Participants and Data Collection}

Three groups of research participants were included:

First group. 15 narrative-interviews with young families were implemented (see Table 1). Criteria for selection of research participants were: young parents (under age of 35); a family has a child / children under age of 12; both partners have had work experience before having a child.

Table 1

Characteristics of young parents' research participants

\begin{tabular}{|c|c|c|c|c|}
\hline \multirow{2}{*}{$\begin{array}{l}\text { Code of interview } \\
\text { participant }\end{array}$} & \multicolumn{2}{|c|}{ Age of parent } & \multirow{2}{*}{$\begin{array}{l}\text { No. of } \\
\text { children }\end{array}$} & \multirow{2}{*}{$\begin{array}{l}\text { Age of child/ children (youngest to } \\
\text { oldest) }\end{array}$} \\
\hline & Mother & Father & & \\
\hline $\mathrm{P} 1$ & 33 & 33 & 2 & 7 years; 12 years \\
\hline $\mathrm{P} 2$ & 34 & 35 & 1 & 7 years \\
\hline
\end{tabular}




\section{sciendo}

10.2478/arhss-2018-0004 Applied Research in Health and Social Sciences, Vol. 15, No. 1, 2018

\begin{tabular}{lllll} 
P3 & 30 & 35 & 1 & 7 years \\
P4 & 35 & 33 & 1 & 8 years \\
P5 & 33 & 34 & 2 & 4 years; 6 years \\
P6 & 34 & 33 & 2 & 3 years; 5 years \\
P7 & 32 & 31 & 1 & 3 years \\
P8 & 29 & 28 & 1 & 0,5 years \\
P9 & 34 & 33 & 2 & 4 years; 6 years \\
P10 & 35 & 34 & 2 & 6 years; 11 years \\
P11 & 31 & 29 & 1 & 5 years \\
P12 & 32 & 32 & 2 & 6 years; 9 years \\
P13 & 32 & 32 & 3 & 4 months, 3 years, 6 years \\
P14 & 29 & 30 & 2 & 4 years; 6 years \\
P15 & 27 & 30 & 1 & 0,5 years \\
\hline
\end{tabular}

Second group. 14 interviews with employers from private and public sectors were conducted (see Table 2). The target group was formed by applying targeted selection method in non-probability sampling.

Table 2

Characteristics of employers' research participants

\begin{tabular}{llll}
\hline $\begin{array}{l}\text { Code of } \\
\text { interview } \\
\text { participants }\end{array}$ & Type of organization/institution & $\begin{array}{l}\text { Number of } \\
\text { employees }\end{array}$ & $\begin{array}{l}\text { Position of the interview } \\
\text { participant }\end{array}$ \\
\hline E1 & Vocational school & 155 persons & Director \\
E2 & Catering institution & 5 persons & Director \\
E3 & University department & 20 persons & Head of the department \\
E4 & Preschool institution & 38 persons & Head \\
E5 & Pro-gymnasium & 72 persons & Deputy director \\
E6 & Lower secondary school & 26 persons & Director \\
E7 & Public limited liability company (raw material & 582 persons & Personnel manager \\
& recycling) & 20 persons & Director \\
E8 & Transport company & 23 persons & Director \\
E9 & Transport and cargo transportation company & Director \\
E10 & Private limited company Foreign Language center & 50 persons & \\
\hline
\end{tabular}




\section{sciendo}

10.2478/arhss-2018-0004 Applied Research in Health and Social Sciences, Vol. 15, No. 1, 2018

\begin{tabular}{llll}
\hline E11 & Individual enterprise (photo services) & 15 persons & Company owner \\
E12 & $\begin{array}{l}\text { Private limited liability company (production of } \\
\text { blanks) }\end{array}$ & 25 persons & Director \\
E13 & $\begin{array}{l}\text { Public institution/health care institution } \\
\text { department }\end{array}$ & 8 persons & Head of the department \\
E14 & Public institution (art area) & 133 persons & Director
\end{tabular}

Third group. 6 career counselling experts participated in focus group. They were selected according to their suitability to the goals of the research (see Table 3).

Table 3

Characteristics of experts in career counselling

\begin{tabular}{llll}
\hline $\begin{array}{l}\text { Code } \\
\text { interview } \\
\text { participants }\end{array}$ & Type of organization/institution & $\begin{array}{l}\text { Position of } \\
\text { interview } \\
\text { participant }\end{array}$ & $\begin{array}{l}\text { Experience in career } \\
\text { counselling field }\end{array}$ \\
\hline CC1 & University Career center & Head & 5 \\
CC2 & University Career center & Specialist & 3 \\
CC3 & Private kindergarten & HR & 6 \\
CC4 & Lithuanian Labor Exchange, Youth Dpt. & Head & 5 \\
CC5 & University Career center & Head & 11 \\
CC6 & Enterprise & HR & 4 \\
\hline
\end{tabular}

\section{Tools and Data Analysis}

All three research instruments were prepared based on results and reports from theoretical and empirical studies conducted by other authors in this field. In narrative interviews the following sequence of life stages has been followed: child birth -> maternity/paternity leave (1-2 years) -> mother's/father's return to work -> child's start to the kindergarten -> child's start to school.

Semi-structured interview questions covered four main topics, i. e. the establishment of familyfriendly workplace; the importance of flexible work schedule; the needs of young parents having young kids; and the developments of conducive organizational culture for young parents with young kids. Questions for experts in focus groups covered topics about career guides' and Human resource (HR) specialists' experiences with employees having young families, reconciliation of their career 


\section{sciendo}

10.2478/arhss-2018-0004 Applied Research in Health and Social Sciences, Vol. 15, No. 1, 2018

and family, analyzing career plans for young parents and employees, identifying potential barriers and motivational measures, allowing to develop and reconcile work and family life as well as necessity for cooperation between a young employee and career or HR specialist.

Analysis of interviews with young parents are based on the narrative analysis method (Soderberg, 2006) and are retold through different life stages from expecting a child and child-birth, especially emphasizing of experiences when returning to work after maternity or/and parental leave, reallocation of responsibilities in the family in reaction to child needs, support of family members, career planning and change management, employer's support and considerations for flexible forms of work for the young families. Research data analysis is presented through singled-out topics and sub-topics and consistent interpretation of these topics. The data analysis has been conducted through paradigmatic analysis (Virgilaite-Meckauskaite \& Mazeikiene, 2012), i. e. firstly, the themes were formulated and then, themes were ranked based on their relevance. Research results of semi-structured interviews with employers and focus group with experts in career counselling are presented through method of text analysis described by Satu \& Kyngas (2008). Deductive approach was applied to distinguish categories and subcategories.

\section{Findings}

Young parents' perspective. Narratives with young parents have revealed the explicit aspect and challenge of the family model that has changed after the baby was born. At that moment, most mothers and fathers feel emotional, physical and psychological transformation from "I" into "Mother"/ "Father" (see Figure 1).

This phenomenon is especially significant after the birth of the first child, although parents who have more than one child shared experiences on stronger lack of 'Self-identity' as most of the time and energy, apart from work, is spent for arranging family duties, logistical issues, distributing roles and duties among family members, etc. This change is extremely difficult at the moment when mother and/or father decides to return to work after maternity/paternity leave because this moment is not just about the decision of who will take care of the baby but as well, what are the possibilities for changing career, seeking for better position, working full time or even workload. Every parent challenges 


\section{sciendo}

10.2478/arhss-2018-0004 Applied Research in Health and Social Sciences, Vol. 15, No. 1, 2018

himself of being a good professional at work and at the same time being a good parent even though this challenge is hardly achievable:

I think that at the beginning a mother is the most important, but when the child grows, a father is increasingly important - as a man I can give things that the mother is less able to give and thus my role is increasingly growing. We have daughters, but sports - such as bikes or swimming - is the thing that I may give, training the children and thus my role is increasing. The other thing is that my job is related to physical activity, and my mature adulthood in terms of physical strength in 27 to 35 is running to an end, when then I am becoming a mature employee and a better parent. Children grow, change and their needs change. (P12)

Research participants represented dual career couples mainly, research results have revealed that these couples are more open for continuous dialogue, search for compromises and for extended family support perceiving these factors as a must for all life fields: family welfare, work and career as well as managing positive changes:
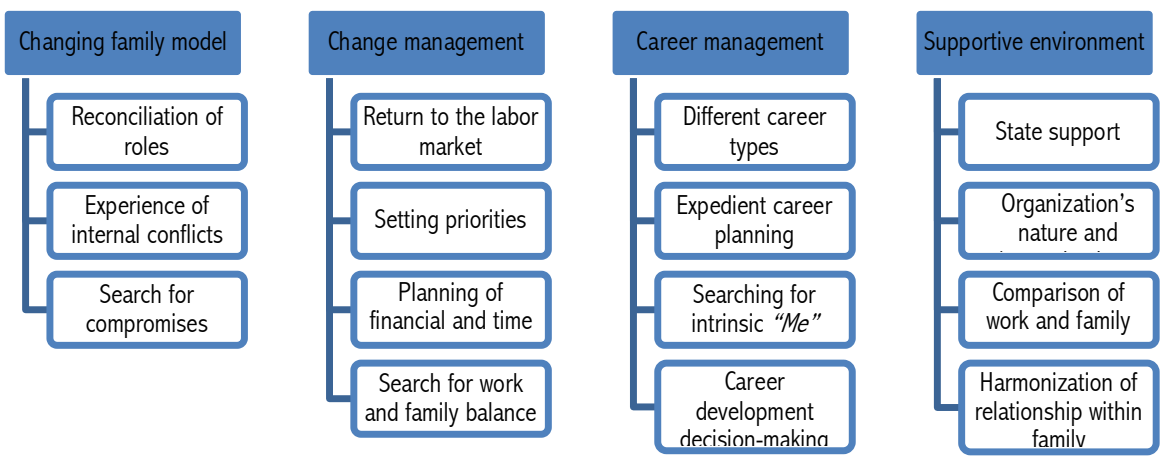

Figure 1. Young parent's perspective

Husband's support is huge. He is doing his best for me to keep improving and not focusing on solely the child bringing. He understands that I may not stop my career and have to return to work after a year ... (P8)

Young parents emphasized that employers who are parents themselves, regardless from age of their children, are more open to search for flexible solutions and compromises when there is a need and especially when they see that young parent-employee is trying to achieve best results while being at work. 


\section{sciendo}

10.2478/arhss-2018-0004 Applied Research in Health and Social Sciences, Vol. 15, No. 1, 2018

Employers' perspective. Analysis of employers' interviews highlighted that employers had overall positive approach towards young parents (see Figure 2). Employers are open for dialogue, discussions and search for new possibilities in the process of reconciliation:

...if there is no urgent work in the company and the employee has some days when the workload is smaller, we allow him / her to leave work... (E11)

Even though sometimes there are strict rules or situations when employer must implement his/her duties and cannot leave the work place, research participants have expressed willingness and initiative in organizing consultations for employees on how to balance between parenthood duties and liabilities at work.

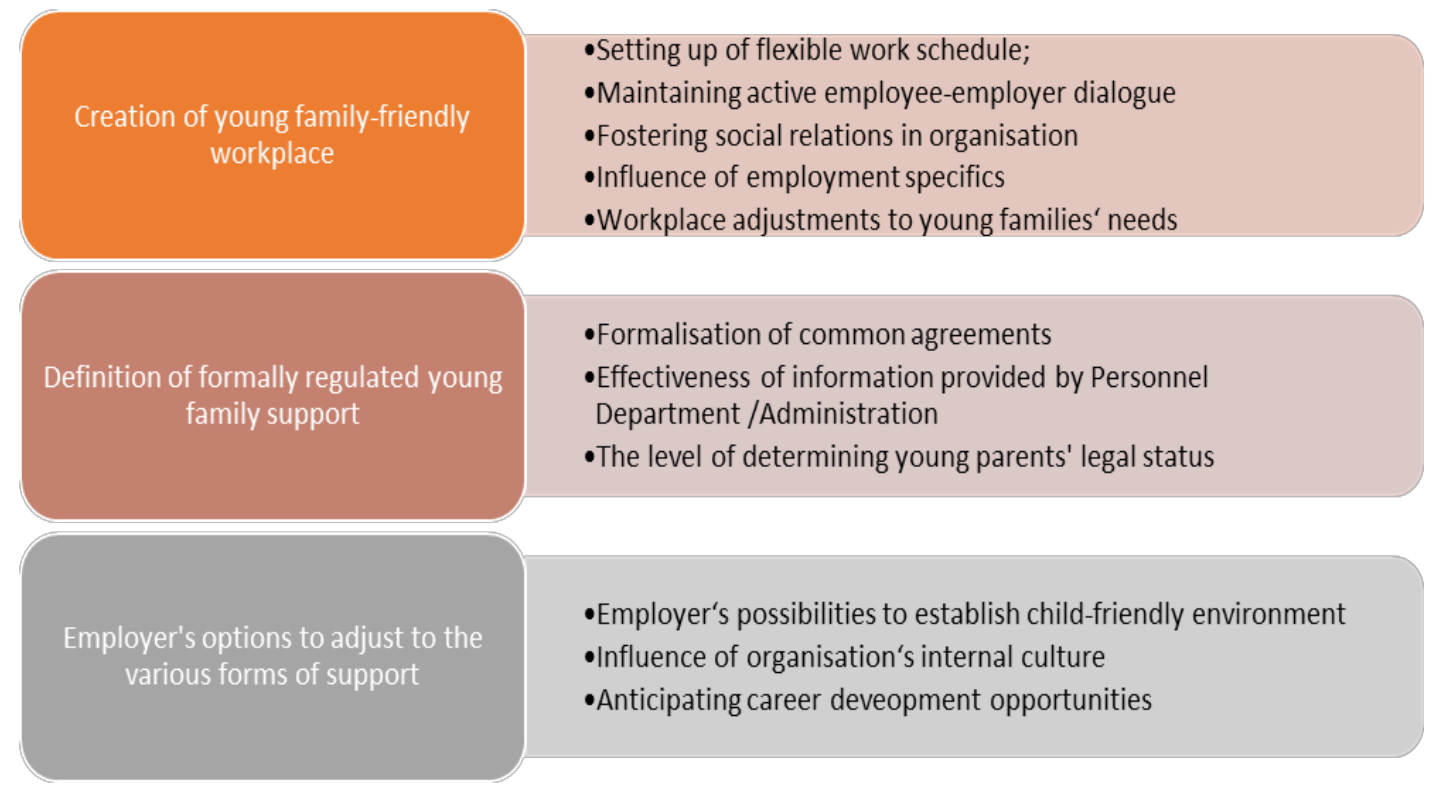

Figure 2. Employers' perspective

As another factor enabling facilitation of duties at work and family, according to research participants could be organization of workshop, where different solutions could be discussed and analyzed in order to find adjustment for the needs of young parents who return to work after maternity/paternity leave: ...if there is a need, it is possible to adjust the circumstances and conditions in relation to what kind of job the employee has to do and how, and what are the opportunities to do it out of the workplace environment. If it does not influence or otherwise harm the job quality, it can be done 


\section{sciendo}

\subsection{8/arhss-2018-0004 Applied Research in Health and Social Sciences, Vol. 15, No. 1, 2018}

remotely. We have used this method successfully, so far there haven't been any specific negative cases... (E8)

Apart from various activities implemented by employers, internal structural and organizational decisions and organizational legal aspects are equally important. As far as employers are reasonable and aware of employees with small children who may expect more flexible working environment, various alternations and solutions can be found.

As one of the very important factors for quality improvement regarding young parents' consultation and support services, employers distinguished the need for external experts' support. When discussing about family-friendly workplace environment, employers see experts' involvement as a crucial point. They expressed the need to develop experts' consultation service, where all parties at the workplace (employers and employees) would learn about their legal status and rights at regarding possibilities facilitate work and family more easily. Moreover, some of interviewees shared the expectations to create the new workplace for career consultant or human resource specialist who would help to develop the whole system for young parents work and family accommodation, and in this way, help young employees avoid difficulties through the transitional period. In this case, it is very important to discuss about parenthood-career reconciliation, management of organization and internal organizational support system.

Career counsellors' perspective. Career counsellors are expected to be the ones who actively participate and could support in planning and managing "career portfolio", career stages as well as planning possible retreat roads. Besides, these specialists could be the initiators for dialogue and situation facilitators to balance career and family life for employees with young children.

Focus group discussion with experts in career counselling pointed out that there are several main issues when considering this specific problem. Firstly, many employees are not aware that career counsellors or HR specialists may provide professional support in reconciling family with young children and work-related needs, leading to a dialogue between employer and employee to create a facilitation "package" oriented to the indicators of young specialist success taking responsibilities at work and in the family thus not confronting but facilitating both loads. Secondly, in many cases young employees are not aware of the benefits that are available on the institutional level and do not dare to discuss with the employer about the possible career paths, changes or possible adaptations after the 


\section{sciendo}

10.2478/arhss-2018-0004 Applied Research in Health and Social Sciences, Vol. 15, No. 1, 2018

increase of the family. This is especially to be said about legislation related to looking for a new job, interviewing with potential employers, etc. Apart from this, various other factors have been distinguished after the text analysis.

Experts raised an important question of young parents' readiness to change the work by being active and critical members of this process. Employers shared concerns that in some cases, young parents might not be aware of their rights during job interviews, e. g. interview questions should be oriented towards evaluation of interviewees' competences but not the family status.

Focus group with career counsellors and human resource experts allowed to distinguish the following categories and subcategories (see Figure 3).
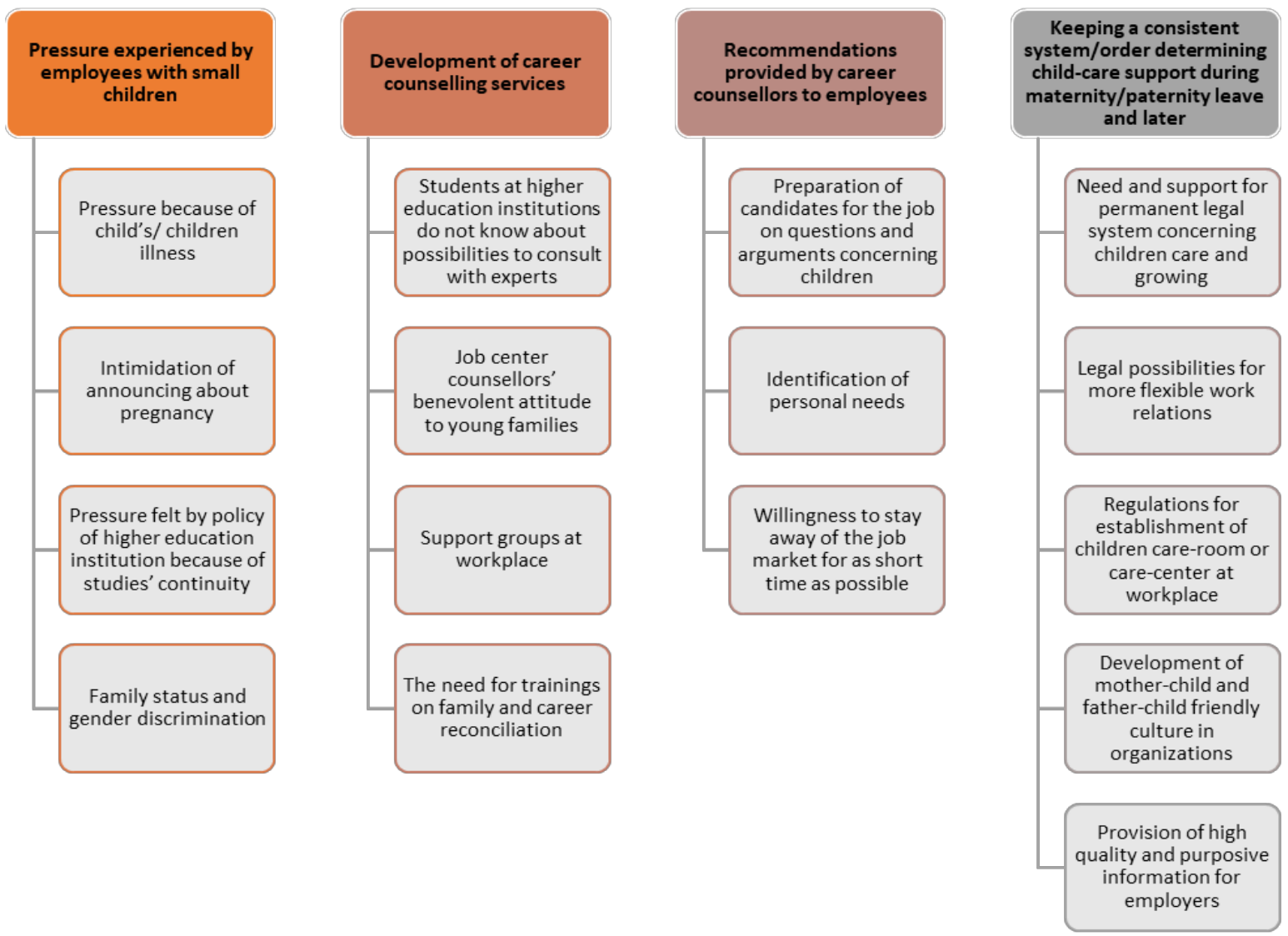

Figure 3. Career counsellors' perspective

According to career counsellors', candidates should be prepared to positively answer questions about children, demonstrate their trust in themselves and abilities to manage situation, plan time, 


\section{sciendo}

10.2478/arhss-2018-0004 Applied Research in Health and Social Sciences, Vol. 15, No. 1, 2018

communicate with employer giving no opportunities for discrimination. Although employees/candidates must know and be confident that it is optional to disclose their personal information related to family status and children:

Job interview is a kind of negotiation object where conditions can be applied as well, for example, I disagree to work on weekends, or extra hours because I must pick up my child from kindergarten. (CC2)

Career counsellors must be deeply aware of how individual, work and family factors might intertwine and how these relations might be used to facilitate parenthood and career most appropriately.

Even though they have basic knowledge on how these processes and consultations must be managed and embodied, another problem occurs that parents don't know or don't trust counsellors as providers of possible support for balancing family and career by presenting different work-family management strategies.

\section{Discussion}

Seeking to distinguish needs and challenges of young families, employers and career counsellors for successful reconciliation of family and career, in depth qualitative research has been implemented. It is important to note that research was implemented seeking to present situation analysis in Lithuanian context although the data is analyzed through the perspectives of international researches conducted in this field.

Interviews with both parents confirmed discussion about the changing family models, where most of fathers (gender aspect) are expected to become more active in child care process, and as a result, they experience quite intensive and stressful transformation process from 'Me' to 'Father'. While transformation from 'Me' to 'Mother' appeared as less stressful. This transition was emphasized by some research participants who acknowledge that mothers have inborn feelings and instincts while fathers' experience and knowledge grow in parallel with a growth of a child. The challenge of new time planning skills, flexibility, role distribution and adjustment to children needs is widely discussed in scientific literature. The participation of both partners in this research, extended approach towards a challenging process of work and career reconciliation by underlying importance of open and 


\section{sciendo}

10.2478/arhss-2018-0004 Applied Research in Health and Social Sciences, Vol. 15, No. 1, 2018

continuous dialogue between spouses, which appeared to be quite a challenging issue. When partners are oriented towards their personal careers and the aspect of togetherness disappears the challenges for reconciliation may appear more frequently. It might be the question of 'culture of silence' where big part of society is not willing to speak out about their needs, require for better work conditions, ask for help, employees are not communicating to employers about problems they face.

The given context emphasizes a need for career consultants' involvement into the process of family and career facilitation. Experts in career counselling play an advocacy role for young working parents in order to find possibilities for flexible work schedules and more varied work forms (e.g., teleworking). Career counsellors or HR specialists in the organizations could act as mediators between employer and employees, helping to adapt work schedule possibilities for employees with young children, possible support and facilitation schemes and planning career stages as well as possible ways for retreat.

Employers offer more flexible schedules, family-friendly policies, professional consultations for adjusting work duties with parenthood responsibilities (Neault \& Pickerell, 2005; Mjoli, 2013).

The aspect of parenthood as a phenomenon for togetherness, is a new approach to this research that revealed the need for dialogue, openness and courage to ask for help. It is important to discuss on how both parents in a mutual unity seek for understanding and support in a family in the context of family and career reconciliation. As well as a role of career counselors, as professional supporters and agents among all target groups who participate in this process and need for their competence development appeared as an important issue for future discussions and researches.

Research limitations. Authors of the article are aware of the limitations of the study that do not diminish the significance of this research. There are two main limitations that should be considered when reading this research paper. Firstly, despite that fact, that research problem is analysed and discussed from three different perspectives (interviews with employers and young families, and focus group with career counsellors), number of research participants does not allow to generalize results representing experiences of all young families, employers and career counsellors. For the more generalised results, quantitative research could be conducted with the target groups mentioned above. The second limitation is the subjectivity of researchers experiences. Specially, this limitation is related 


\section{sciendo}

10.2478/arhss-2018-0004 Applied Research in Health and Social Sciences, Vol. 15, No. 1, 2018

with interviews with families. Interviews with both parents were challenging and it might have influenced the stories shared.

\section{Conclusions}

As data analysis have revealed, advantage of one of IT tools could be taken for family and work reconciliation. It allows more flexibility in terms of working hours and teleworking as well as telecounseling could be considered to make career guidance more accessible for young families.

Career counsellors confirmed fears expressed by parents that employers are not willing to employ young people who are planning to have a baby or already have one. Even though employers say that competency at workplace is more important than family status research results reveal that this attitude might still demonstrate the lack of family friendly culture on all levels, i.e. personal, institutional and national. Nevertheless, the importance of personal need identification was clearly pointed out by all research participants: parents distinguished it as a tool buffering potential internal family conflict, employers see this as an easier way for employee to stand up for his needs, especially when decisions must be made, and, finally, career counsellors point out that this identification must be made while children are small and at the most vulnerable.

Finally, the need for negotiation and sharing is of great importance so that all target groups participating in the process of family and work reconciliation would share, discuss and be open about their needs, expectations, challenges and other issues important for common welfare.

\section{Acknowledgement}

The financial support provided by the Research Council of Lithuania for the research is gratefully acknowledged (Project Reg. No. MIP-075/2014).

\section{References}

1. Ahmad, A. (2007). Work-family conflict, life-cycle stage, social support, and coping strategies among women employees, The Journal of Human Resource and Adult Learning, 3(1), 70-79.

2. Ahmad, A. (2008). Job, family and individual factors as predictors of work - family conflict. The Journal of Human Resource and Adult Learning, 4(1), 57-65. 


\section{sciendo}

10.2478/arhss-2018-0004 Applied Research in Health and Social Sciences, Vol. 15, No. 1, 2018

3. Coser, L., A. (1974). Greedy institutions. Patterns of undivided commitment. The Free Press: New York.

4. Mjoli, T, Dywili, M. \& Dodd, N. (2013). Demographic determinants of work - family conflict among female factory workers in South Africa. Journal of Economics, Business and Management, 1(1), 30-41.

5. Moen, P. (2003). It's about time: Couples and careers. ILR Press Books.

6. Neault R.A. \& Pickerell D.A. (2005). Dual-career couples: The juggling act. Canadian Journal of Counselling, 39(3), 187-198.

7. Soderberg, A.M. (2006). Narrative interviewing and narrative analysis in a study of a cross-border merger. August Management International Review, 46, 397-416.

8. Virgilaitè-Mečkauskaitè, E. \& Mažeikienè, N. (2012). Biografinio tyrimo galimybès tiriant magistrantų tarpkultūrinès kompetencijos ugdymąsi socializacijos procese. Kokybiniai edukaciniai tyrimai: Teorijos, duomenu rinkimas ir analize. Šiauliai: VŠI Šiaulių universiteto leidykla.

9. Wayne J.H., Musisca N. \& Fleeson W. (2004). Considering the role of personality in the work-family experience: Relationships of the big five work-family conflict and facilitation. Journal of Vocationl Behavior, 64, 108-130.

10. Satu, E. \& Kyngas, H. (2008). The qualitative content analysis process. Journal of Advanced Journal, 62(1), 107115.

Submitted 2018-07-15

Received 2018-07-15

Accepted 2018-09-19 